\title{
Method of identification of useful functions in the scope of technical system development
}

\author{
Marek Mysior ${ }^{1}$ [0000-0002-9973-704X](凶), Witold Hnat ${ }^{2}$, Sebastian Koziołek ${ }^{1}$ \\ ${ }^{1}$ Wroclaw University of Science and Technology, Department of Machine Design \& Research, \\ Łukasiewicza 7/9, 50-371 Wroclaw, Poland \\ ${ }^{2}$ Mine Master Sp. z o.o., Wilków ul. Dworcowa 27, 59-500 Złotoryja Poland \\ marek.mysior@pwr.edu.pl
}

\begin{abstract}
Proper understanding of customers' needs is of great importance in developing strategy for a technical system development. Current description of those needs is based on customers' opinions and experience. This description rarely resembles parameters of the system-to-be-developed that are changing in time. The aim of this study was to develop a method for useful function identification that will take into account evolution of not only a technical system, but also customers' needs. This approach consists of problem identification in the context of an expected outcome in order to identify customers' needs in the form of evaluation parameters. Those parameters are further analyzed to define required functions of the system-to-be-developed by means of functional analysis. During the study, such TRIZ tools like Function Analysis and System Operator were implemented to model useful functions and context of development of technical system. Innovation Assessment methodology was applied to assess obtained results of the study. Application of proposed method of identification of useful functions during technical system development makes it possible to create product development strategies that take into account evolving needs of customers at early design stages. This allows reduction of $R \& D$ costs and resources usage in the design process
\end{abstract}

Keywords: TRIZ, Function Analysis, Inventive Engineering, Useful Function.

\section{Introduction}

Nowadays, design of inventions is not an easy task. According to TRIZ [1-4], ideality of technical system is never declining throughout its evolution, what translates into necessity of new functions being implemented to the system with simultaneous reduction in harms and costs. On top of that, needs of customers evolve in time, creating new perspectives for technical system development. People get used to solutions that are available on the market, which makes products outdated. As shown in [5], to maintain stable level of innovativeness of the products and/or processes, it is necessary to maintain a specific share between attributes of attractiveness, linear quality and must be within the system. This is especially difficult if one take into account evolving needs of customers, which makes this share change. This creates an urgent need to take into 
account migration of attributes, so that the system designed will maintain its high, stable level of innovativeness in response to those changes. To do this, it is necessary to have knowledge on which functions of a technical system will be attractive to customers in the future, which will be linearly related to customers' satisfaction and which will represent basic requirements. One solution to that may be the use of technology forecasting and roadmapping methods [6-12] to determine priorities in research and to specify what the system to be forecasted will look like in the future, but even if applied, technology roadmapping often do not result in positive innovation performance outcomes [8, 13, 14]. This knowledge, even if obtained and used with success, gives only an overview of both expected technical system traits and customers' needs, but there is very limited concern in assessment of innovativeness of systems-to-be-designed with respect to those evolving needs. There are several methods on how to measure innovativeness of products that were summarized in [5], but there is lack of method that would take into account evolution of needs and changes in useful functions. This paper proposes novel approach in design systems to-be in the future taking into account evolving needs of customers. As a base for this work, Innovation Assessment Method shown in [15, 16] was chosen and extended for the scope of defined task.

\section{Materials and Methods}

The proposed method of identification of useful functions in the scope of technical system development is based on forecasting future needs and taking them into consideration at the stage of parameters selection for innovation assessment. In this work, stepby-step approach was described how to determine useful functions of a technical system, how to identify their evolution and how to take them into account during innovation assessment method. In the later part of this work, proposed approach was shown on real life example of underground mining bolting machine used in Copper Mines in Poland. Proposed method consists of 3 steps as described on fig. 1. For each step, set of tools was proposed, based on $[15,17]$. At first it is necessary to define and formulate a problem that is being dealt with. This problem formulation includes, but is not limited to functional modelling of the system that helps to fully understand the core of the problem from the point of view of useful and harmful functions. Having functions defined, the next step is to determine system parameters ${ }^{1}$ describing those functions in a measurable way on a level of system, super-system and sub-system. Those parameters are required to determine key parameters ${ }^{2}$ of the technical system, which are parameters that describe useful functions of the analyzed system and represent add-ed value to the customer. In TRIZ, those parameters are often referred to as MPV (Main Parameters of Value), which are parameters that create customer satisfaction and play important role in customer purchase decision [18]. There are other works in which authors identified MPVs of products to plan their development, which involved application of fuzzy logic [19] and S-curve analysis [20]. The approach proposed by Malinin [19] makes it possible to identify development strategies based on MPVs in a systematic way. There is

System parameters- parameters describing functions of a technical system

2 Key parameters- system parameters that represent value for customers 
however very limited description on how to identify those parameters in a systematic way. Identification of MVPs proposed by Lok [18, 20] concentrates on qualitative market research methods to identify MPV, which do not form a scientific evidence and confidentiality in proper selection of those parameters.

In this paper, authors present a novel approach to identify useful functions and their key parameters in a systematic way through functional decomposition of a system. In the following chapters, each step of the proposed approach is described and application of this method is presented.

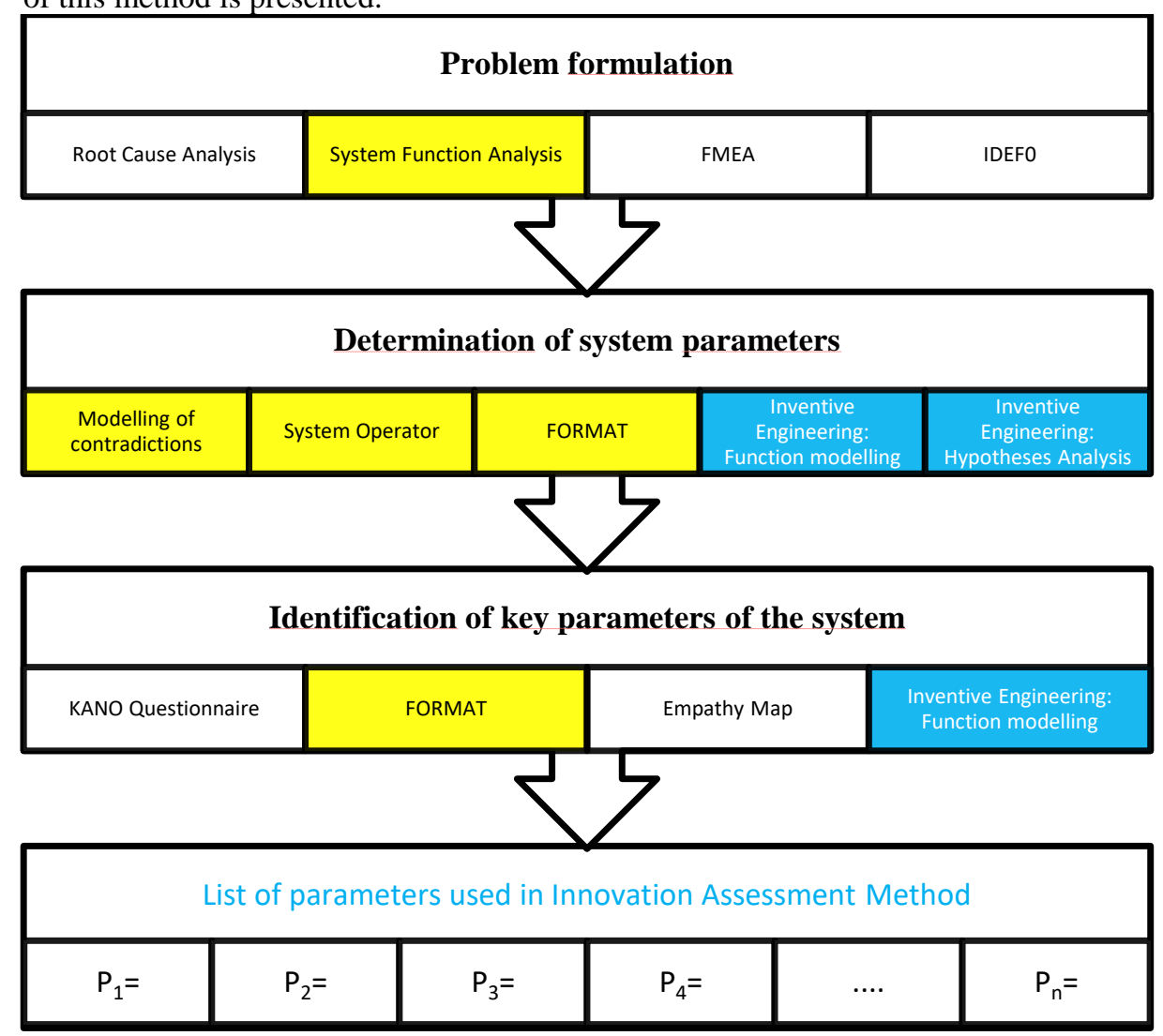

Fig. 1. Overview of the proposed method of identification of useful functions

The first step in a proposed approach is to formulate the problem that limits development of a specific product. According to TRIZ, technical systems evolve by elimination of contradictions and thus increase of their ideality [4]. This problem can be referred to as a main function being realized by a technical system. For example, technical system being dedicated to transport and storage of compressed biogas has a main outcome of <delivered biogas>, which is a result of a function <to transport> [21]. Determination of a main outcome of a given system and its main function can be 
determined using various tools like IDEF0, System Function Analysis or Root Cause Analysis.

Having main function defined, it is important to identify parameters describing effectiveness (performance) of the analyzed system. Those parameters describe its behavior in respect to all the actions that are being realized by the system as a result of interaction of system components with each other and with supersystem. For example, biogas transportation system can be described by such parameters as storage pressure [Pa] and volume $\left[\mathrm{nm}^{3}\right]$, methane content [\%] etc. Those parameters can be obtained using several TRIZ tools, for example System Operator (9 boxes) or modelling of contradictions or tools described in Inventive Engineering, such as function modelling and hypotheses analysis [15].

Having those parameters described, it is necessary to identify those that contribute to customers' value. For this purpose, technology forecasting methods may be used in order to identify Main Parameters of Value (MPV) and choose them for further analysis in innovation assessment method. It is also possible to question customers on what is important for them (Kano Questionnaire) or use an Empathy Map to identify customers' needs. Those parameters are being referred to as key parameters and are subjected to innovation assessment in order to identify development strategy for a given technical system [5].

\section{$3 \quad$ Results: case study}

Results of application of proposed approach are shown on an example of underground roof bolting machines used in copper mines. Roof bolting process is a very dangerous process in which free walls and ceiling of the mine face is being bolted with adjacent layers of rock in order to minimize a risk of roof fall, which is one of the biggest threads in underground mining both in Poland [22] and worldwide [23]. This process consists of several steps which require both manual and automatic work of the machine, operated by operator. The aim of this case study was to design a roof bolting machine that will be innovative and will address customers' needs in the most appropriate way both in the short-term and long-term future. For this to be possible, it was necessary to define key parameters of roof bolting machines that are today and those that will be significant in the future.

\subsection{Problem formulation in design of bolting machine}

At first problem formulation step was performed in which the process of bolting was described using IDEF0 function modelling [24] to name useful functions of the system. This is shown on fig. 2 and 3. This tool is very efficient in knowledge acquisition for every analyzed system or process. The main outcome of the bolting machine is bolted ceiling that protects operators and miners in harsh environment near the mine-face. This area is one of the most dangerous areas in the mine, that is why ceiling in those places has to be secured as soon as possible. This means, that efficiency of bolting is directly related to efficiency of the entire copper extraction process. 


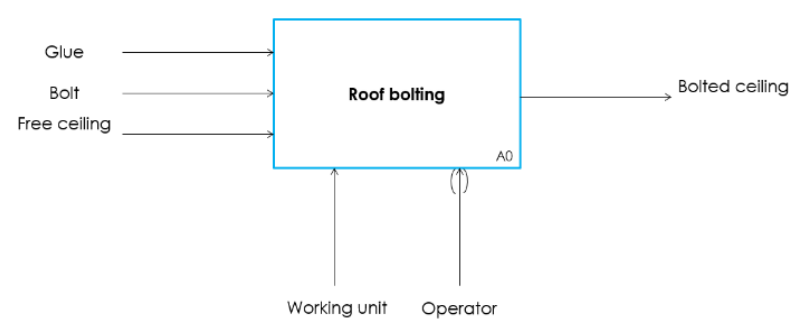

Fig. 2. IDEF0 of the roof bolting process, node A-0.

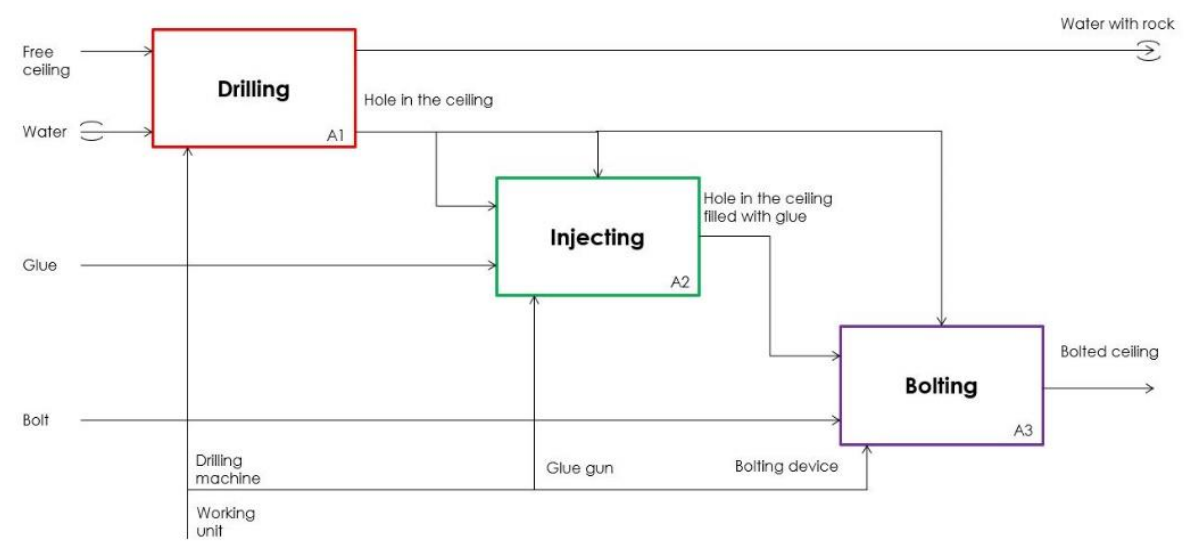

Fig. 3. IDEF0 of the roof bolting process, node A0.

Based on functions defined in IDEF0, it was possible to define useful functions of the system that were further used to evaluate measurable parameters of a roof bolting machine.

\subsection{Determination of system parameters}

Having functions of the system identified it is important to define parameters describing those functions in quantitative way. This may be performed using many different tools, but in this case study, tabular method based on definition of functions, their requirements and methods on how to satisfy those requirements was used. This method was described on an example of thermal insulation materials in [16]. Results of this analysis are presented on fig. 4 . 
As it was shown on fig. 2, there are 3 main functions that can be identified within the process of roof bolting:

- drilling, in which hole in roof/wall is being prepared that is dedicated for mounting of bolts. Usually, drilling is realized by drill rod with cutting rods using various types of equipment, such as rotary drills, percussion drills and so forth. Some methods involve also drilling with water (wash drilling) to eliminate loosened rock from the hole as drilling progresses. Alternative method to this include Airmist and Air spraying;

- injecting. In this operation, glue is being delivered to the drilled hole that will serve as adhesive holding rocks together after bolting. There are several ways of injecting glue into the hole, but the main result is the same. There are also important considerations regarding positioning of glue gun in the axis of previously drilled hole, which is very important for the process to be effective;

- bolting. This is the process in which actual bolt is being screwed into the drilled hole, mixing injected glue and attaching to layers of rock in the roof or walls. There are several types of bolts used, but for the purpose of this work only expandable bolts were analyzed.

Each function above was described in terms of requirements, which are conditions that have to be satisfied in order to deliver desired outcome, methods on how to satisfy those conditions and parameters describing how effective those conditions are satisfied, which translates directly to effectiveness of the realized function.

Similar outcome may be achieved using other tools, such as Hypotheses Analysis that is part of Inventive Engineering [25], TRIZ Contradiction Modelling [17, 26] and many others.

Parameters described on fig. 4 are related to the system being analyzed. For the analysis to be complete and to make it possible to identify key parameters of the roof bolting machines, it is necessary to determine even more parameters that are related to the customers needs. Because roof drilling machine being the scope of this work works in underground copper mine, as a super-system, underground copper mine was defined. Sub-system of the roof drilling machine is defined as bolts, drills and other equipment used to make roof bolting operations. 


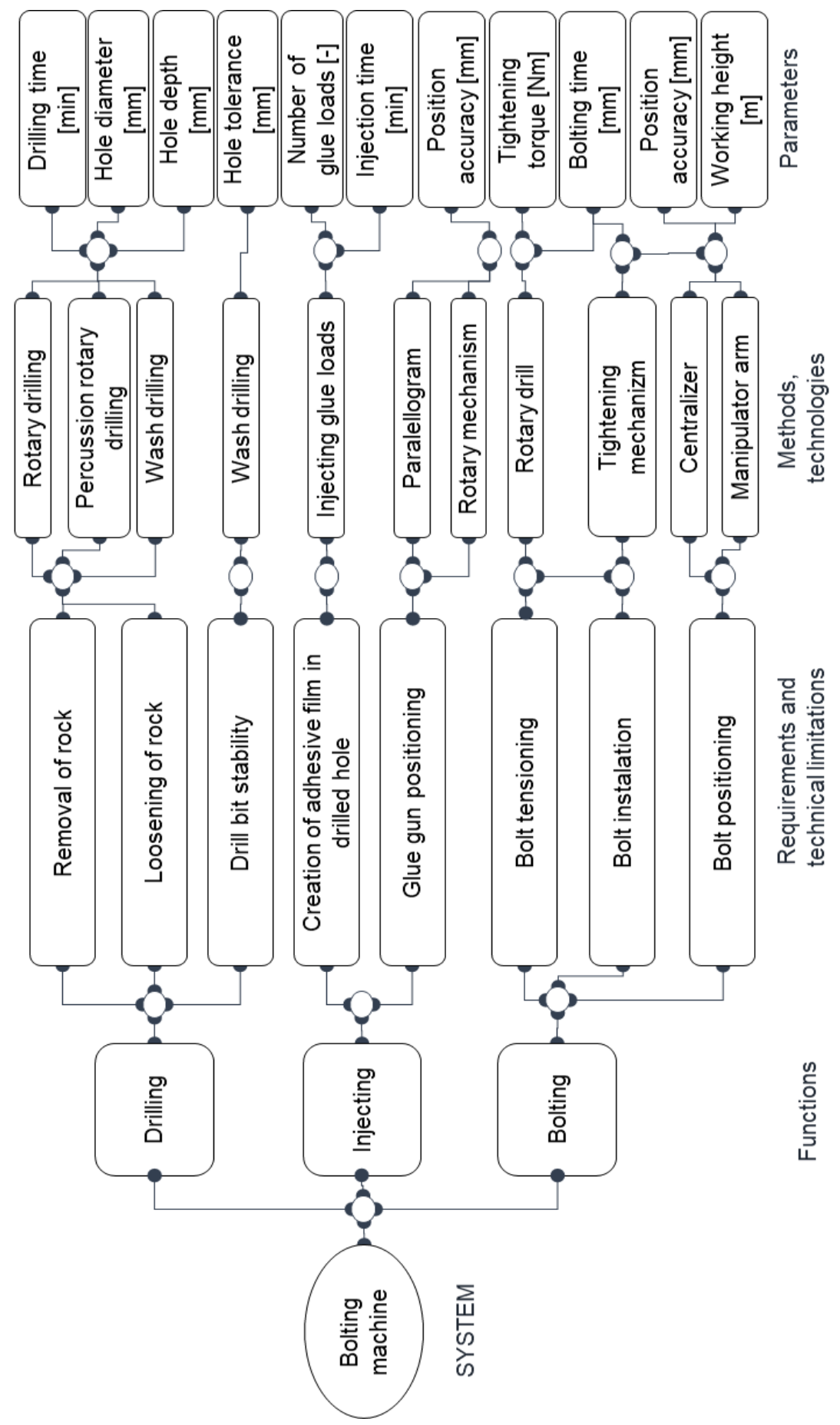

Fig. 4. Model of extraction of parameters from useful functions 
System Operator of roof bolting system in underground copper mine is presented on fig. 5. Results presented on the fig. 5 were obtained using technology forecasting method FORMAT and are presented in the form of a single picture showing evolution of a mine, bolting machines and bolting equipment.

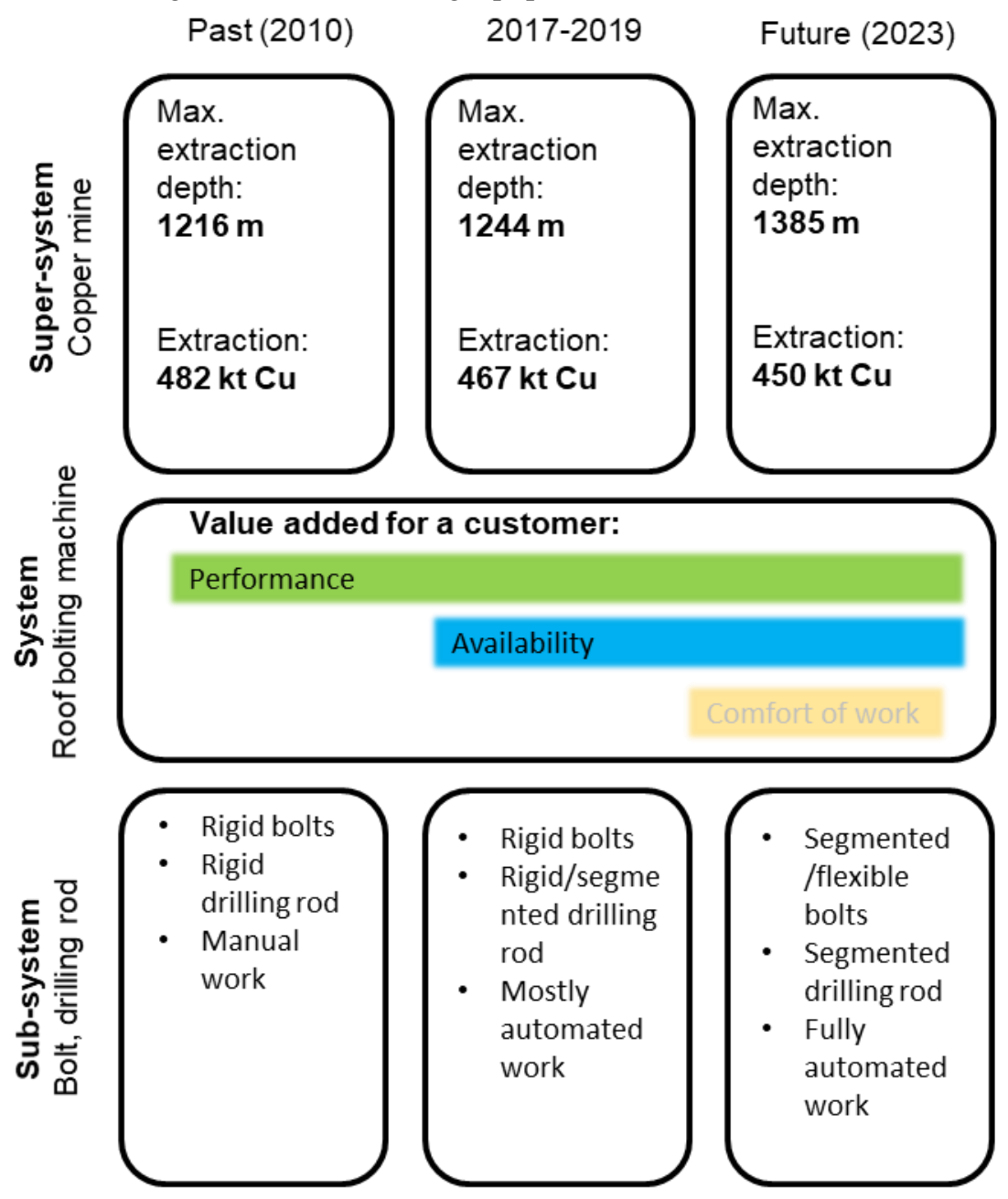

Fig. 5. System Operator of roof bolting system

From the point of view of a copper mine, the most important parameter that resembles customers' needs is extraction depth. Polish copper mines, in order to satisfy slightly decreasing extraction rate need to explore ores that are deeper underground [27]. This creates set of problems that have to be addressed in the nearest future. As it was shown in [28], exploration of deeper ores means reduction in ore height, what has a great impact on a roof drilling machines. The smaller the ore height, the lower machine should be to be effectively operated in future mine. The significance of the problem is 
additionally shown on fig. 6 which shows share of ore extraction in biggest copper mines in Poland, for every which ore height is shown [28]. It can be observed, that there is a trend in increase rate of extraction of copper and silver ore from mines having low ore which means, that it is getting more and more important to design machines capable of working in smaller working height. What is also important, the higher the depth, the higher the temperature in the mine, making very harsh environment for the operator to work in. This makes it necessary to limit amount of time the operator spends outside of the machine.

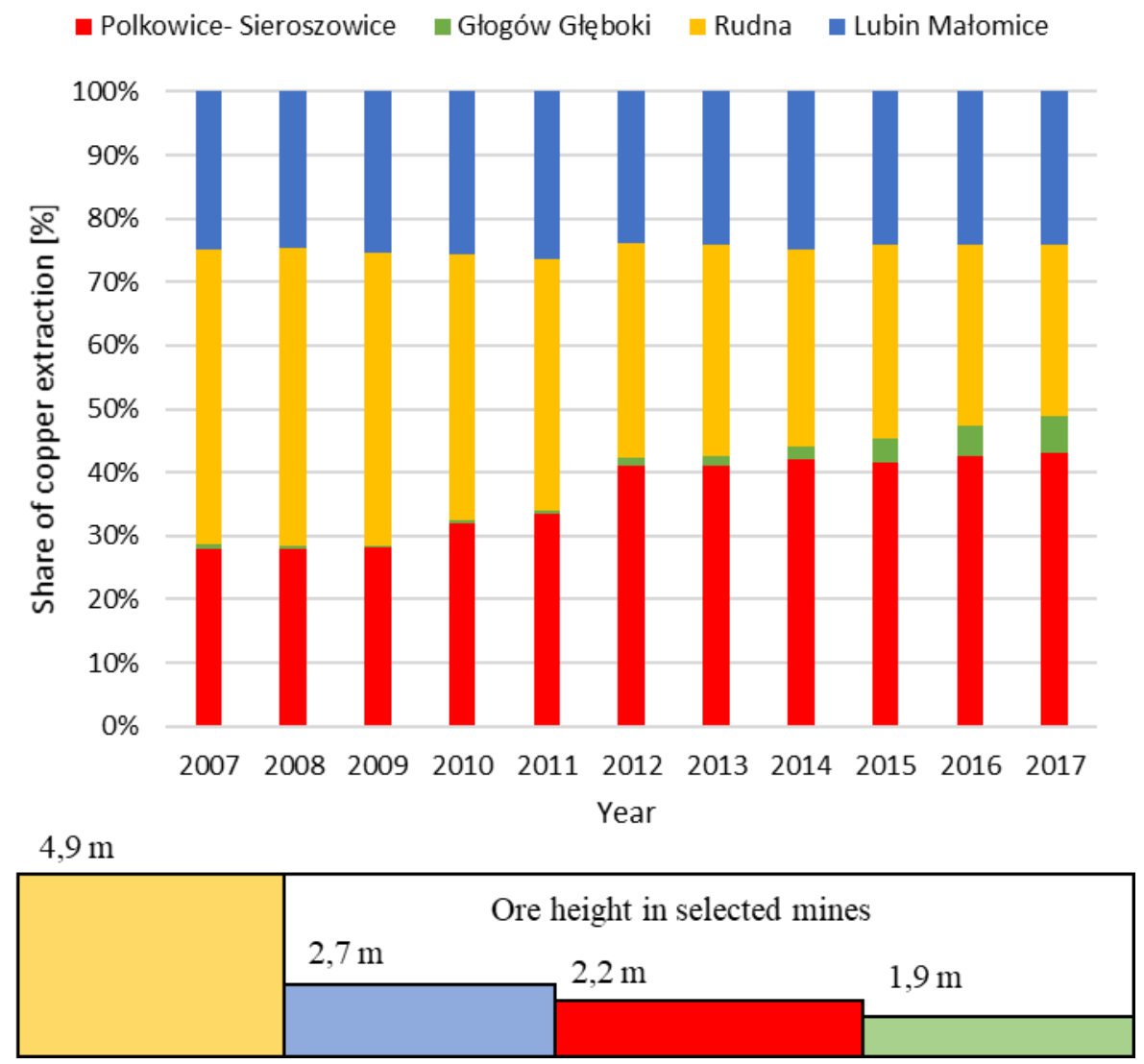

Fig. 6. Share of copper extraction in polish mines and average height of ore in those mines.

Results of technology forecasting, combined with parameters describing technical system, it is possible to define key parameters of the roof bolting machine. 


\subsection{Identification of key parameters of the system}

Key parameters of the system are being extracted based on results of technology forecasting method in the form of parameters describing super-system of a designed system. It was shown, that the most important parameters describing future mine are:

- SS1:depth of copper and silver ore extrusion [m],

- SS2: height of the copper and silver ore, determining height of the front of the mine [m],

- SS3: temperature in the mine $\left[{ }^{\circ} \mathrm{C}\right]$,

- SS4: Ore extraction [kt/year].

Those parameters are then verified, if they influence any of the parameters describing the technical system. Results are shown in table 1 which shows matrix of influence of super-system parameters on system parameters. Those parameters of the system that are being influenced by super-system parameters are called key parameters and represent value added to customers and users of those machines.

Table 1. Influence of parameters of super-system on system parameters

\begin{tabular}{|c|c|c|c|c|c|c|c|c|c|c|c|}
\hline & 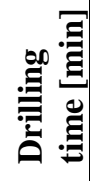 & 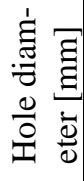 & 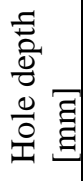 & 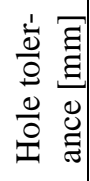 & 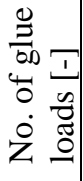 & 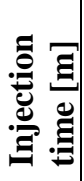 & 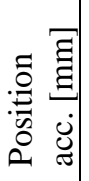 & 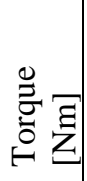 & 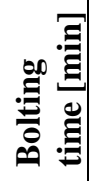 & 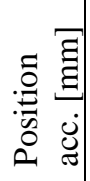 & 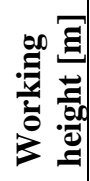 \\
\hline SS1 & & & & & & & & & & & \\
\hline SS2 & & & & & & & & & & & $X$ \\
\hline SS3 & $\mathrm{X}^{3}$ & & & & & $X$ & & & $\mathrm{X}^{3}$ & & \\
\hline SS4 & $X$ & & & & & $X$ & & & $X$ & & $X$ \\
\hline & 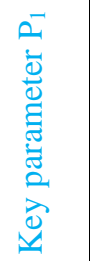 & & & & & 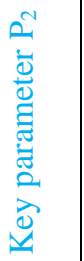 & & & 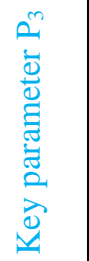 & & 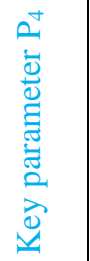 \\
\hline
\end{tabular}

The table above summarizes, which parameters describing useful function of roof bolting machine are related to customers' satisfaction, thus being key parameters of the designed system.

3 Temperature in mine influences drilling time only if work is being done manually by the operator. If an operator is separated from harsh environment, this is not important. 


\section{Discussion}

As a result of conducted case study and developed method, it was possible to determine key parameters that are responsible for customers' satisfaction in the future based on results of technology forecasting. Those parameters are summarized once again in table 2. It was shown in the case study, that for development of roof bolting machines it is important to concentrate on aspects connected with working height of the machine, because future working environment will be getting lower. This is a direct result of necessity of extraction of copper ore from deeper levels in order to maintain nearly stable extraction rate. This in turn means, that environmental conditions will be getting more and more difficult for operators, which will require either minimizing of time spent outside of the machine by operator or introduction automated machines in which operator sits in air conditioned cabin, separated from harsh environment.

\begin{tabular}{|l|l|}
\hline $\begin{array}{l}\text { Key parameters } \\
\text { at the super-system level }\end{array}$ & $\begin{array}{l}\text { Key parameters } \\
\text { at the system-level }\end{array}$ \\
\hline SS1:depth of ore extrusion $[\mathrm{m}]$, & $\mathbf{P}_{1}$ : Drilling time $[\mathrm{min}]$ \\
$\begin{array}{l}\text { SS2: height of the copper and silver ore, deter- } \\
\text { mining height of the front of the mine }[\mathrm{m}],\end{array}$ & $\mathbf{P}_{2}$ : (Glue) injection time [min] \\
SS3: temperature in the mine $\left[{ }^{\circ} \mathrm{C}\right]$, & $\mathbf{P}_{3}$ : Bolting time [min] \\
SS4: Ore extraction $[\mathrm{kt} / \mathrm{year}]$. & $\mathbf{P}_{4}:$ Working height $[\mathrm{min}]$ \\
\hline
\end{tabular}

Key parameters describing a technical system being developed should be then assigned attributes of attractiveness, linear quality or must be and further evaluated to present innovativeness of specific technical solution, as shown in [5].

\section{Conclusions}

In the article, method of identification of useful function in the scope of product development was developed. In this method, key parameters of system to be designed are determined based on results of technology forecasting and functional analysis of the system. After this, dependence of parameters of super-system, sub-system and system is defined, which makes it possible to identify key parameters representing customers' needs. Proposed approach is not limited to technology forecasting and roadmapping, but also makes it possible to assess innovativeness of the developed products based on forecasted needs, reducing R\&D costs and increasing probability for successful implementation of a solution to the market. It is yet to be determined, how to verify if the list of key parameters that was defined is complete. That will require further work in case studies based on proposed approach and verification of its effectiveness on other examples outside mining industry. 
Acknowledgements: Research conducted by Marek Mysior was funded by the Ministry of Science and Higher Education in Poland, grant number 0402/0072/18, dedicated to young researchers.

\section{References}

1. Zlotin, B., Zusman, A.: Directed Evolution: Philosophy, Theory and Practice. Ideation International Inc. (2001).

2. Orloff, M.: Inventive thinking through TRIZ: A practical guide. (2006). https://doi.org/10.1007/978-3-540-33223-7.

3. Altshuller, G.S.: The innovation algorithm: TRIZ, systematic innovation and technical creativity, (2007).

4. Altshuller, G.: And Suddenly the Inventor Appeared. Tech. Innov. Cent. (2004). https://doi.org/10.3324/haematol.2009.020586.

5. Pryda, B., Mysior, M., Koziołek, S.: Method of Innovation Assessment of Products and Processes in the Initial Design Phase. In: Automated Invention for Smart Industries. pp. 75-83 (2018). https://doi.org/10.1007/978-3-030-02456-7_7.

6. Abe, H., Ashiki, T., Suzuki, A., Jinno, F., Sakuma, H.: Integrating business modeling and roadmapping methods - The Innovation Support Technology (IST) approach. Technol. Forecast. Soc. Change. (2009). https://doi.org/10.1016/j.techfore.2008.03.027.

7. Daim, T.U., Oliver, T.: Implementing technology roadmap process in the energy services sector: A case study of a government agency. Technol. Forecast. Soc. Change. (2008). https://doi.org/10.1016/j.techfore.2007.04.006.

8. Carvalho, M.M., Fleury, A., Lopes, A.P.: An overview of the literature on technology roadmapping (TRM): Contributions and trends. Technol. Forecast. Soc. Change. 80, 1418-1437 (2013). https://doi.org/10.1016/j.techfore.2012.11.008.

9. Saritas, O., Aylen, J.: Using scenarios for roadmapping: The case of clean production. Technol. Forecast. Soc. Change. (2010). https://doi.org/10.1016/j.techfore.2010.03.003.

10. Lee, S., Lee, S., Seol, H., Park, Y.: Using patent information for designing new product and technology: Keyword based technology roadmapping. R D Manag. (2008). https://doi.org/10.1111/j.1467-9310.2008.00509.x.

11. Groenveld, P.: Roadmapping integrates business and technology. Res. Technol. Manag. (2007). https://doi.org/10.1080/08956308.2007.11657472.

12. Cascini, G., Ramadurai, B., Słupiński, M., Rabie, M., Becattini, N., Kaikov, I., Kucharavy, D., Nikulin, C., Koziołek, S., Festa, E.: Knowing the future is possoble. The handbook. (2015).

13. Vatananan, R.S., Gerdsri, N.: The Current State of Technology Roadmapping (TRM) Research and Practice. Int. J. Innov. Technol. Manag. 09, 1250032 (2012). https://doi.org/10.1142/S0219877012500320.

14. Cooper, R.G.: Product innovation and technology strategy. Res. Technol. Manag. (2000). https://doi.org/10.1080/08956308.2000.11671329.

15. Koziołek, S.: Inżynieria Wynalazczości. Metodologia projektowania innowacyjnych systemów technicznych. Oficyna Wydawnicza Politechniki Wrocławskiej, Wrocław (2019). 
16. Koziołek, S.: Design by Analogy: Synectics and Knowledge Acquisition Network. In: Rusiński, E. and Pietrusiak, D. (eds.) Proceedings of the 13th International Scientific Conference. pp. 259-273. Springer International Publishing, Cham (2017).

17. Bukhman, I.: TRIZ Technology for Innovation. Cubic Creativity Company (2012).

18. Lok, A.: Combination of Hidden Customer Needs tools and MPV to generate product concept. Presented at the (2016).

19. Malinin, L.: Technology selection based on main parameters of value and fuzzy logic. Int. J. Bus. Innov. Res. 11, 431 (2016). https://doi.org/10.1504/IJBIR.2016.10000079.

20. Lok, A.: MPV-based Engineering System Evolution. In: Proceedings of the MATRIZ TRIZfest 2017 International Conference. , Kraków (2017).

21. Koziołek, S., Białowiec, A., Mysior, M., Ptak, M., Słupiński, M., Derlukiewicz, D.: Rozproszone systemy dystrybucji biogazu: badania, projektowanie i rozwój. Oficyna Wydawnicza Politechniki Wrocławskiej, Wrocław (2017).

22. Karliński, J., Ptak, M., Działak, P., Rusiński, E.: The approach to mining safety improvement: Accident analysis of an underground machine operator. Arch. Civ. Mech. Eng. 16, 503-512 (2016). https://doi.org/10.1016/J.ACME.2016.02.010.

23. Helander, M.G., Krohn, G.S., Curtin, R.: Safety of roof-bolting operations in underground coal mines. J. Occup. Accid. 5, 161-175 (1983). https://doi.org/10.1016/0376-6349(83)90002-0.

24. Inc, K.S.: IDEFO.

25. Mysior, M., Koziołek, S., Rusiński, E.: Problem Formulation of Screw Feeding System of Fibrous Materials Using TRIZ. In: Advances and Impacts of the Theory of Inventive Problem Solving (2018). https://doi.org/10.1007/978-3-319-96532-1_5.

26. Gadd, K.: TRIZ for Engineers: Enabling Inventive Problem Solving. Wiley (2011).

27. KGHM Polska Miedź SA: Strategy for 2023. (2017).

28. Konopko, W., Piernikarczyk, A.: Koncepcja technologii eksploatacji cienkiego złoża rud miedzi. CUPRUM - Czas. Nauk. Górnictwa Rud. 4, 17-33 (2014). 